\title{
REPAIR OF RC BEAMS WITH OPENINGS SUBJECTED TO TORSION USING STEEL PLATES
}

\author{
Ahmed Rashad Shalaby* \\ PHD. Student, Structural Engineering Department, Cairo University, Giza, Egypt \\ Ghada Diaa \\ Professor, Housing and Building National Research Center, Egypt \\ Hany Abdalla \\ Professor of Concrete Structures, Cairo University, Giza, Egypt \\ *Corresponding Author
}

\begin{abstract}
This paper presents the results of an experimental investigation on the behavior of $R C$ beams with openings repaired by steel plates and subjected to pure torsion. The experimental study includes testing of seven $R C$ beams divided into three groups. The parameters considered in this study include the steel plates configuration, opening width and steel plate thickness. The experimental work consists of one solid specimen, four specimens with openings of $300 \times 150 \mathrm{~mm}$ and two specimens with openings of 500 $x 150 \mathrm{~mm}$. The results of the tested beams include cracking and ultimate torques, angle of rotation, toughness, and mode of failure. A cost effectiveness study was performed to compare the different repair configurations used in this research. The experimental results showed that using full steel plates in repairing beams with opening significantly improved the ultimate torsional capacity of such beams.
\end{abstract}

Keywords: RC beams; Repairing; Opening; Steel plates; Torque

Cite this Article: Ahmed Rashad Shalaby, Ghada Diaa and Hany Abdalla, Repair of Rc Beams with Openings Subjected to Torsion Using Steel Plates, International Journal of Civil Engineering and Technology, 11(10), 2020, pp. 58-73.

https://iaeme.com/Home/issue/IJCIET?Volume $=11 \&$ Issue $=10$

\section{INTRODUCTION}

In the last decades, the torsional moment was considered to have a minor effect on the different structural elements, and most of design engineers ignored it. As a result of that, they increased safety factors by depending on conservative flexural design and on the stirrups provided for the 
shear design. In many structural members, the torsional moment is one of the main steps in the design process which governs the design. These members include curved girders, edge beams of slabs and shells, spiral stairs and eccentrically loaded beams.

Many researches were carried out on RC members subjected to pure torsion or torsion combined with bending, shear and normal force which their provisions were available in various codes. These codes do not provide special guidelines for the design of RC beams with openings subjected to torsion. Openings are important in RC beams for passing the utility ducts and pipes which are necessary to accommodate the essential services like electricity, air condition, water supply, computer networks and telephones. Passing these ducts through opening in the beams, leads to great saving in the space below such beams causing reduction in the overall height of the building. The repairing or strengthening of beams is a need to enhance their properties such as strength capacity, torsional strength, toughness and ductility to withstand the additional loads applied to the existing structure members.

The influence of the number of openings, the spacing between stirrups, and depth of beams on the torsional behavior of simply supported RC beams with openings were investigated by Abdo and Mabrouk [1]. Mansur et al. [2] investigated the torsional behavior of reinforced concrete beams with large rectangular opening. The behavior of $\mathrm{T}$ - shaped $\mathrm{RC}$ beam specimens with large rectangular openings subjected to pure torsion was studied by Salama et al.[3]. Makhlouf [4] studied the torsional behavior of strengthened beams. His research concentrated on the influence of strengthening by steel stirrups and steel links techniques on the torsional behavior of $\mathrm{Z}$ shaped beams with openings. Also, Holman and Cook [5] investigated the torsional behavior of RC spandrel beams repaired using adhesive bonded steel plates.

According to Etman and Marzouk [6], strengthening of solid beams subjected to pure torsion with steel plates increased the ultimate torque by $22 \%$ compared to control beam. Fawzy [7] studied the influence of using steel plates and carbon fiber reinforced polymer (CFRP) sheets on the torsional behavior of strengthened RC specimens with and without opening. He found that using steel plates was more effective than FRP in increasing the torsional capacity and toughness of the specimens. Fawzy et al. [8], found that strengthening of RC beams with and without opening by different configurations of CFRP sheets increased the ultimate torque especially the configuration of $90^{\circ}$ wrapping of both top and bottom chords and solid parts around the opening.

Domat [9] investigated experimentally and analytically the influence of strengthening RC beams subjected to torsion with CFRP sheets. The results indicated that full wrapping technique was the most effective configuration in resisting torsional moment. Also, strengthening using CFRP strips having an angle of $45^{\circ}$ with the beam axis increased the ultimate torsional capacity compared to vertical strips. The spacing between strips was also a significant factor in resisting torsional moment. Atea [10] studied the influence of using CFRP laminates in strengthening RC flanged T-beams subjected to torsion. He found that using anchors with CFRP strips wrapping was more efficient than strips without anchors. Moreover, wrapping the web and flange separately did not show significant improvement in torsional capacity.

Hekal et al. [11], investigated the torsional behavior of RC beams strengthened with Steel or CFRP Plates with different techniques. It was concluded that all strengthening techniques improving the torsional capacity, ductility specially while using CFRP plates or steel plates fixed by both epoxy and steel dowels. Askandar and Mahmood [12], studied the effect of using Near-Surface Mounted Steel Bars (NSM) in strengthening RC beams subjected to torsion and bending. They found that using NSM steel bar improved the torsional resistance and decreased the ductility of all beams. Moreover, the $90^{\circ} \mathrm{NSM}$ steel bar configuration was more effective than the $45^{\circ}$ NSM steel bar configuration. 
Kandekar and Talikoti [13], investigated the torsional behavior of RC beams strengthened with aramid fiber reinforced polymers, AFRP. The results showed that full wrapping and strips of $100 \mathrm{~mm}$ width schemes improved the ultimate and cracking torques of the tested beams by $140 \%$, and $80 \%$ respectively. According to Alabdulhady et al.[14], strengthening of RC beams with fiber reinforced cementitious matrix (FRCM) composites was considered one of the best techniques that enhanced the torsional behavior. Moreover, the full wrapping configuration was more effective than the U wrapping. Finally, it was found that the influence of PBO-FRCM was similar to that of using CFRP and GFRP composites in strengthening beams subjected to torsion.

In this research, the effect of different configurations of steel plates in the vicinity of the opening is investigated. A cost analysis is also conducted to reach the most effective configuration for the repair process.

\section{EXPERIMENTAL PROGRAM}

\subsection{Materials}

Trial concrete batching was prepared to achieve characteristic strength of $30 \mathrm{~N} / \mathrm{mm}^{2}$ after 28 days. This concrete was used to fabricate seven beam specimens. Super plasticizer and high range water reducing additive (Addicrete BVF, 2017) [15] was added to the mixture to achieve specific workability because of the intensity of reinforcement at top and bottom chords of the opening. The components of the concrete mix used in this research is shown in Table 1.

Table 1 Components of the concrete mix

\begin{tabular}{|c|c|}
\hline Content & ${\text { Unit per } \mathbf{1 ~ m}^{\mathbf{3}}}^{\text {Cement }(\mathrm{kg})}$ \\
\hline Water (Litre) & 350 \\
\hline Coarse Aggregate (Dolomite size No 1) $(\mathrm{kg})$ & 65 \\
\hline Coarse Aggregate (Dolomite Size No 2) $(\mathrm{kg})$ & 625 \\
\hline Fine Aggregate (Sand) $(\mathrm{kg})$ & 625 \\
\hline BVF (Litre) & 4 \\
\hline
\end{tabular}

The steel plates used in strengthening the beam specimens in this investigation were of thicknesses of (3 and 6) $\mathrm{mm}$. A tension test was performed to evaluate their mechanical characteristics and the results were $380.5,432.3$, and $1.902 \times 10^{5} \mathrm{~N} / \mathrm{mm}^{2}$ as yield stress, ultimate strength, and Young's modulus, respectively, with $27.7 \%$ as the elongation for the steel plates of $3 \mathrm{~mm}$ thickness. The corresponding results for the $6 \mathrm{~mm}$ plate were 447.4, 634.7, and $2.24 \mathrm{x}$ $10^{5} \mathrm{~N} / \mathrm{mm}^{2}$ and $24.4 \%$. In addition, high tensile steel bolts of grade (8.8) were used to ensure the full contact between steel plates with concrete surface. The utilized bolts were $200 \mathrm{~mm}$ in length and $12 \mathrm{~mm}$ in diameter. Their mechanical characteristics were 812.9, 964.9, and $4.06 \mathrm{x}$ $10^{5} \mathrm{~N} / \mathrm{mm}^{2}$ as yield stress, ultimate strength, and Young's modulus, respectively, and $66.4 \%$ as ultimate reduction in area. Also, Kemapoxy 165 (2017) [16] was used as an adhesive material between the steel plates and concrete surface. The grades of steel according to the tension test were $36 / 52$ and $24 / 36$ for the main reinforcement and stirrups, respectively, and 37 for the utilized steel plates.

\subsection{Specimen details}

The effect of steel plates configuration, opening width and steel plate thickness are the main parameters considered in this study. Table 2 shows the details of the tested groups. The experimental program included seven RC beams having the same cross-sectional dimensions 
of $150 \times 350 \mathrm{~mm}$ and overall span of $1400 \mathrm{~mm}$. This length was divided into three parts; the middle part was $1000 \mathrm{~mm}$ which was the test zone. The two end parts were $200 \mathrm{~mm}$ in width and $350 \mathrm{~mm}$ in length, and were heavily reinforced to be safe against pre-mature failure during testing. Fig. 1 shows the details of the tested beam specimens. These specimens include one solid beam, four beams with openings of dimensions $300 \times 150 \mathrm{~mm}$ and two beams with openings of dimensions $500 \times 150 \mathrm{~mm}$. The beams were reinforced longitudinally with eight high tensile steel bars of $10 \mathrm{~mm}$ diameter. In addition, two branches closed stirrups made of 6 $\mathrm{mm}$ diameter spaced at $150 \mathrm{~mm}$ were used as a transversal reinforcement. The reinforcement details of the specimens are shown as in Fig. 2.

Table 2 Details of the tested groups

\begin{tabular}{|c|c|c|c|}
\hline Group & Beam No. & Parameter Studied & Repairing Method \\
\hline \multirow{4}{*}{ A } & $\mathrm{C}-0$ & \multirow{4}{*}{ (Full plate \&strips) } & Control beam without opening \\
\hline & C-300 & & Control beam with opening $300 \times 150 \mathrm{~mm}$ \\
\hline & $\mathrm{R}-300-3$ & & $\begin{array}{l}\text { RC beam with opening } 300 \times 150 \mathrm{~mm} \text { repaired by full } \\
\text { steel plates with } 3 \mathrm{~mm} \text { thickness }\end{array}$ \\
\hline & R-300-3-S & & $\begin{array}{l}\text { RC beam with opening } 300 \times 150 \mathrm{~mm} \text { repaired by steel } \\
\text { plate strips with } 3 \mathrm{~mm} \text { thickness }\end{array}$ \\
\hline \multirow{5}{*}{ B } & $\mathrm{C}-0$ & \multirow{3}{*}{ Opening width } & Control beam without opening \\
\hline & C-300 & & Control beam with opening $300 \times 150 \mathrm{~mm}$ \\
\hline & C-500 & & Control beam with opening $500 \times 150 \mathrm{~mm}$ \\
\hline & R-300-3 & \multirow[t]{2}{*}{$(300 \& 500 \mathrm{~mm})$} & $\begin{array}{l}\text { RC beam with opening } 300 \times 150 \mathrm{~mm} \text { repaired by full } \\
\text { steel plates with } 3 \mathrm{~mm} \text { thickness }\end{array}$ \\
\hline & R-500-3 & & $\begin{array}{l}\text { RC beam with opening } 500 \times 150 \mathrm{~mm} \text { repaired by full } \\
\text { steel plate with } 3 \mathrm{~mm} \text { thickness }\end{array}$ \\
\hline \multirow{4}{*}{ C } & C-0 & \multirow{4}{*}{ Steel Plate Thickness } & Control beam without opening \\
\hline & C-300 & & Control beam with opening $300 \times 150 \mathrm{~mm}$ \\
\hline & R-300-3 & & $\begin{array}{l}\text { RC beam with opening } 300 \times 150 \mathrm{~mm} \text { repaired by full } \\
\text { steel plates with } 3 \mathrm{~mm} \text { thickness }\end{array}$ \\
\hline & R-300-6 & & $\begin{array}{l}\text { RC beam with opening } 300 \times 150 \mathrm{~mm} \text { repaired by full } \\
\text { steel plates with } 6 \mathrm{~mm} \text { thickness }\end{array}$ \\
\hline
\end{tabular}

In the above table, $\mathrm{C}$ represents control specimen; $\mathrm{R}$ represents repaired beam; $\mathrm{S}$ represents strips; 0 represents no Opening; (3, and 6) represents steel plate thickness in mm; (300, and 500) represents opening width in $\mathrm{mm}$.

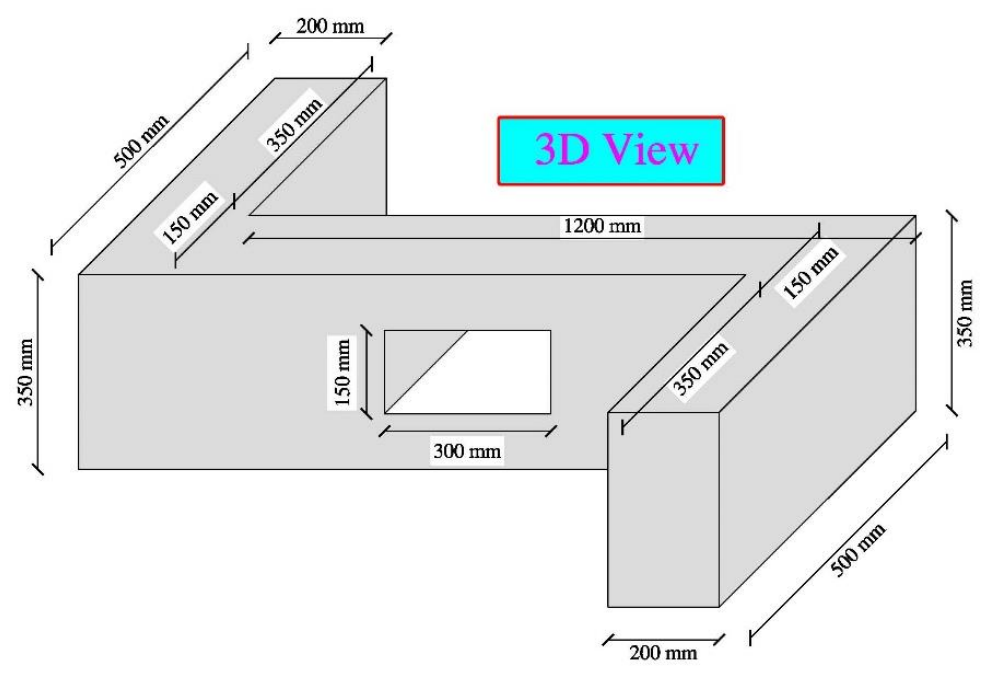


Ahmed Rashad Shalaby, Ghada Diaa and Hany Abdalla

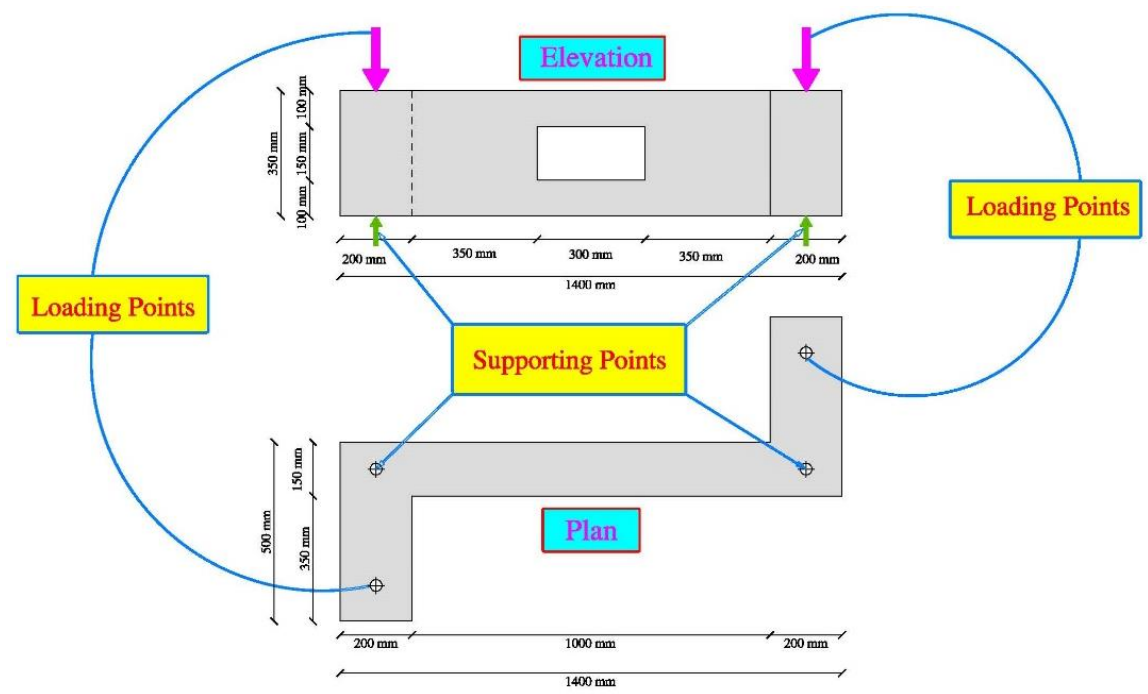

Figure 1 Details of the tested beam specimens
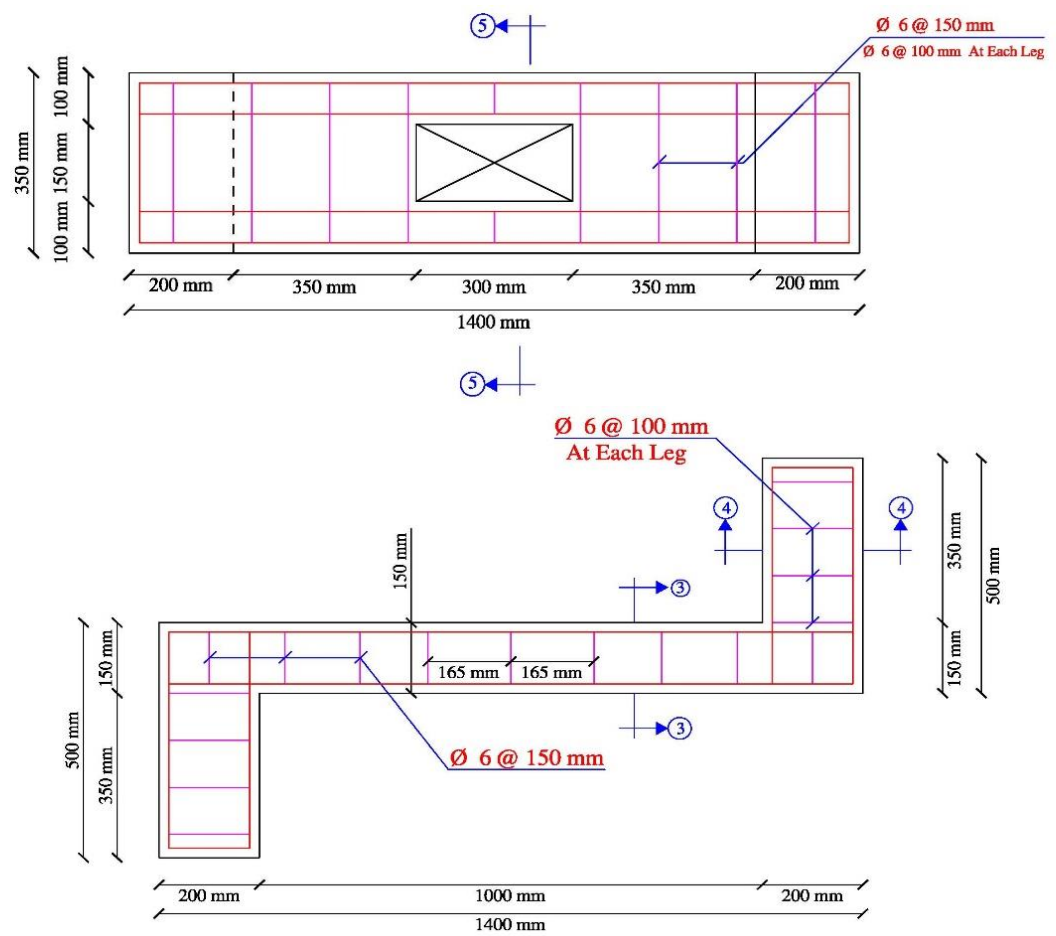

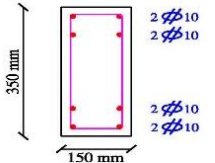

(SEC. 3-3)

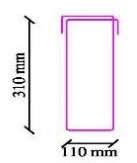

Closed Stirrup Ø6@150 mm

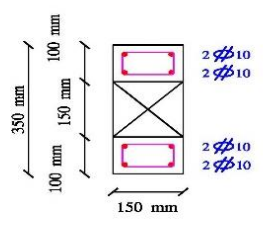

(SEC. 5-5)

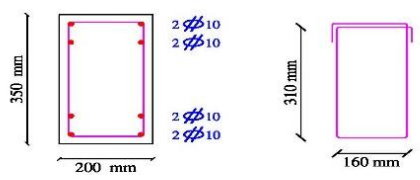

(SEC. 4-4)

Closed Stirrups $\varnothing 6 @ 100 \mathrm{~mm}$

Figure 2 Reinforcement details of specimens 


\subsection{Details of repairing techniques}

The experimental program includes testing of seven RC beams subjected to torsion. Specimens C-0, C-300, and C-500 were used as control beams without repairing. Specimens R-300-3, R300-3-S, R-300-6, and R-500-3 were repaired by steel plates with different configurations and thicknesses. Beam R-300-3 was repaired by one full steel plate with dimensions of $500 \times 350$ $\mathrm{mm}$ in width and depth, and with thickness of $3 \mathrm{~mm}$ on the two sides of the beam. Beam R300-3-S was repaired by using four strips of steel plates with thickness of $3 \mathrm{~mm}$ on the two sides of the beam. Beam R-300-6 was repaired by one full steel plate with dimensions of $500 \mathrm{x}$ $350 \mathrm{~mm}$ in width and depth, and with thickness of $6 \mathrm{~mm}$ on the two sides of the beam. Finally, beam R-500-3 was repaired by one full steel plate with dimensions of $700 \times 350 \mathrm{~mm}$ in width and depth, and with thickness of $3 \mathrm{~mm}$ on the two sides of the beam. Fig. 3 shows the details of repairing configurations.

The beam specimens C-0, C-300, and C-500 were loaded till failure. While specimens (R300-3, R-300-3-S, R-300-6, and R-500-3) were loaded till a diagonal crack due to torsion appeared, then the load was released. These specimens were then repaired and reloaded again till failure. In the repairing process, the locations of the bolts were marked. Then, holes were drilled in the front and back sides of each beam as shown in Fig. 4(a). The concrete surface of specimens was then made free from painting, dust or other impurities by using polishing grinder machine as in Fig. 4(b). The surface of steel plates was then roughened by using a grinder to increase the cohesion between steel plates and the applied KEMAPOXY 165 as shown in Fig. 4(c). The adhesive material (KEMAPOXY 165, 2017) was then applied on the steel plates, bolts and the holes to ensure complete bonding between concrete and bolts. Finally, the steel plates were fixed in their locations and the bolts and nuts were fastened by spanners to ensure full bonding between steel plates and the concrete beam as in Fig. 4(d).
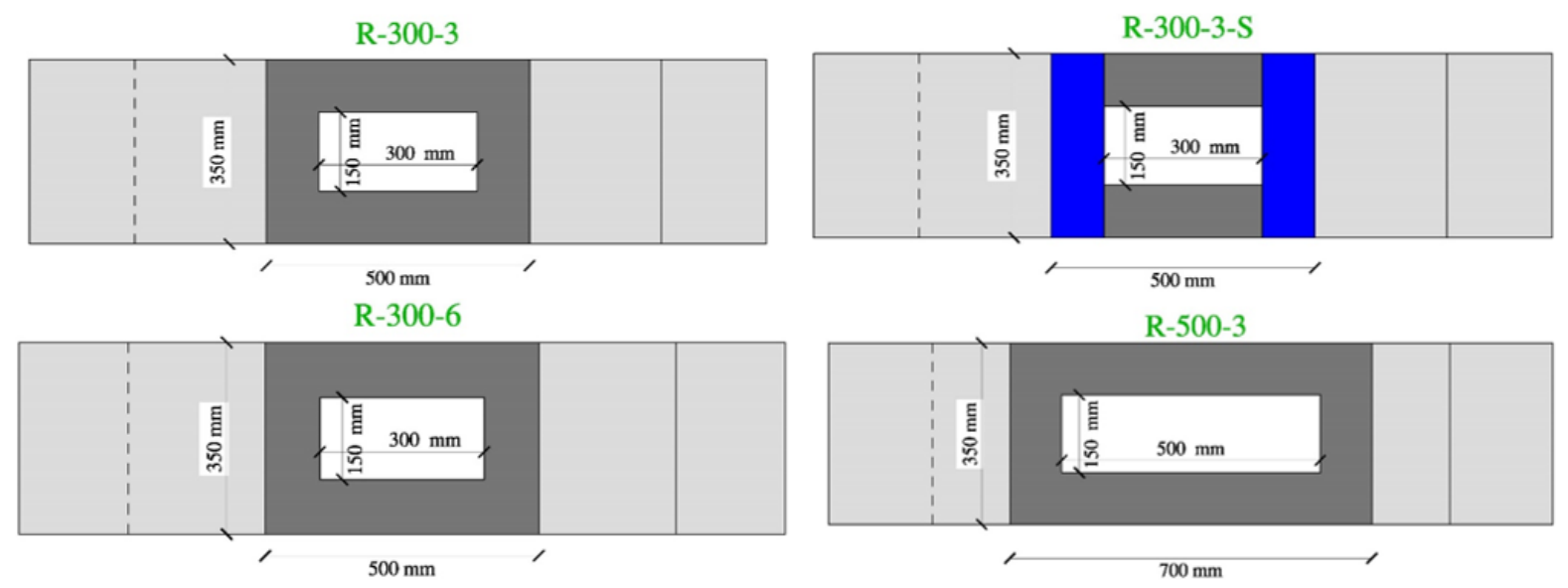

Figure 3 Details of repairing configuration

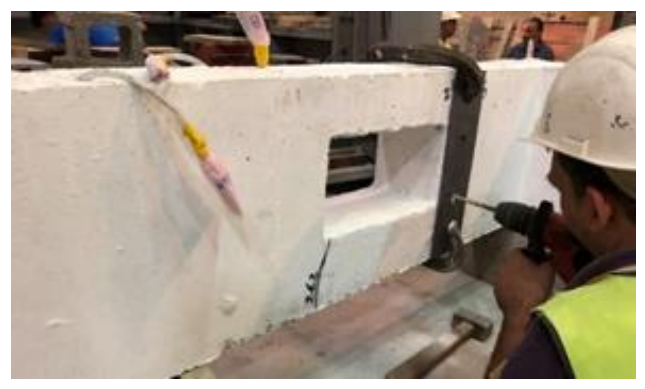

(a) The drilling process of the holes

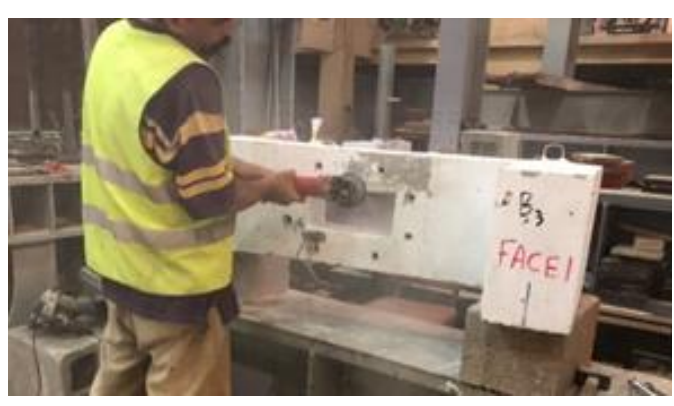

(b) The concrete surface cleaning process 


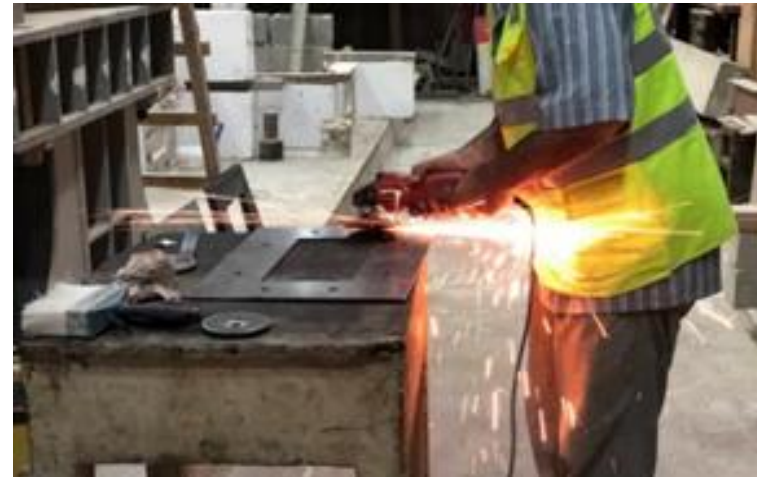

(c) The roughening process of the steel plates Surface

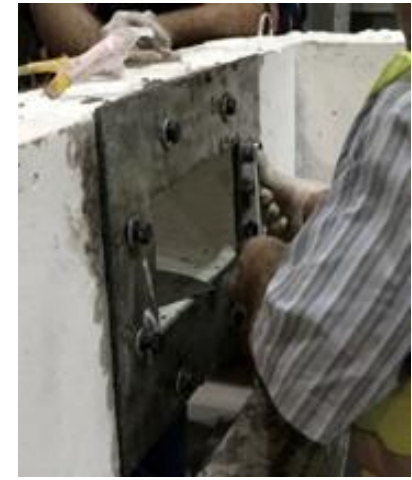

(d) The process of fastening bolts and nuts

Figure 4 Details of repairing process

\subsection{Test setup and instrumentation}

Fig. 5 shows the test setup of the experimental work. The tested specimens were simply supported on movable supports which allowed beams to rotate about its longitudinal axis. Loading was applied by using hydraulic jack with capacity of 100 ton. The hydraulic jack was connected to a load cell which transferred the readings by data logger to be ready in Excel sheet. The applied vertical load was equally distributed on the two concrete cantilevers at both ends of the beam by using a rigid steel I-beam to produce pure torsional moment. Two LVDTs were installed at the mid span of each cantilever to measure the vertical displacement at various loading stages, while the load on each cantilever was applied in increments. The utilized LVDTs were of $100 \mathrm{~mm}$ stroke. All LVDTs readings were recorded in a data sheet. The rotation angles are measured by dividing the average of the two readings of LVDTs at each load by the horizontal distance between LVDT location and the beam centerline. The torque is measured by multiplying the applied force on each cantilever by the horizontal distance between the loading point and the beam centerline.

The reinforcement strain was measured using electrical strain gauges having gauge dimensions of $6 \mathrm{~mm}$ and $2.2 \mathrm{~mm}$ as length and width, respectively. The strain gauges have gauge factor of 2.12 and $120 \mathrm{Ohm}$ as electrical resistance. Before casting the concrete, three strain gauges were placed in each beam. The first strain gauge was located at the first stirrup beside the opening, while the second strain gauge was fixed at edge stirrup and the third strain gauge was placed on the bottom longitudinal bar. Two other strain gauges were installed at the steel plates to measure their strain. The first strain gauge was at the bottom chord steel plate, while the other strain gauge was at the top corner of the steel plate. Fig. 6 shows schematic view for the strain gauges locations.

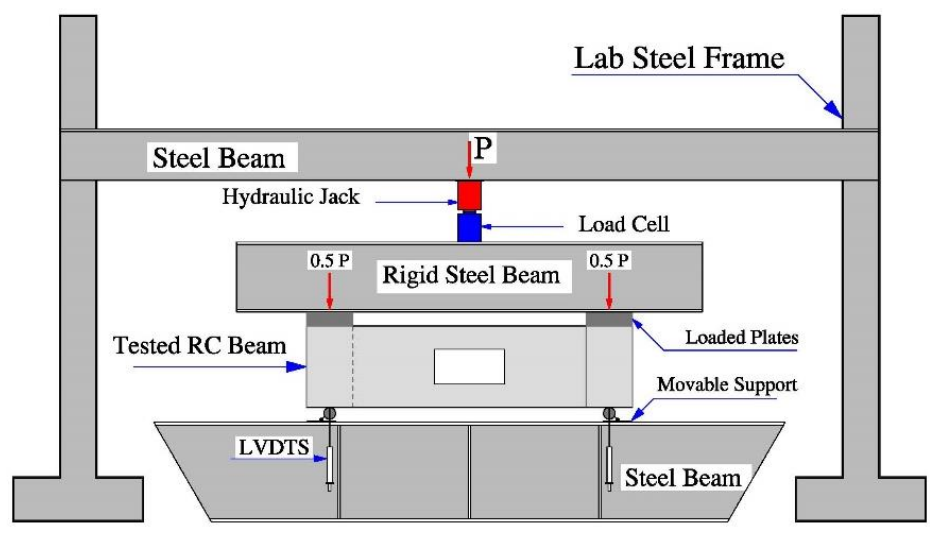




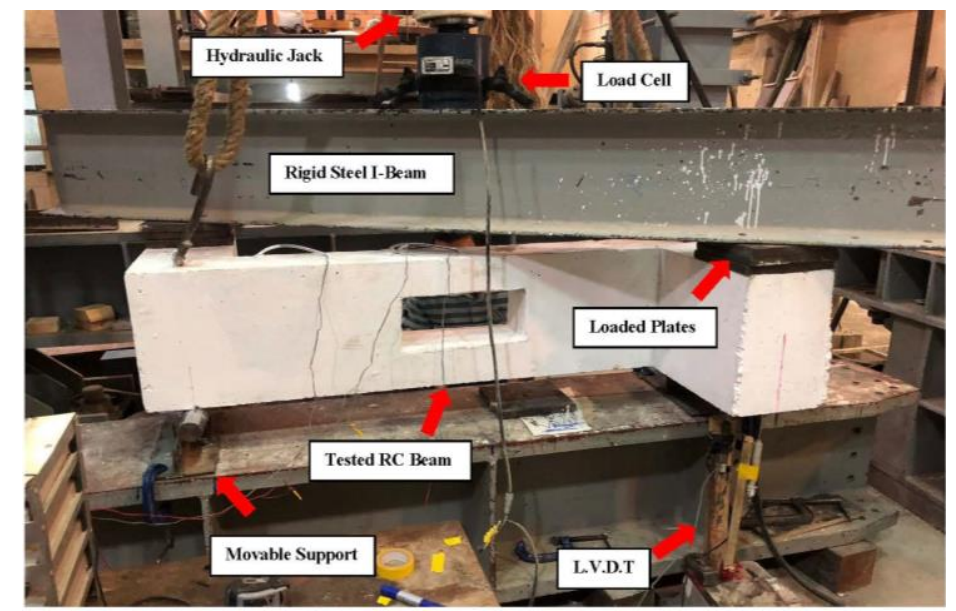

Figure 5 Test setup
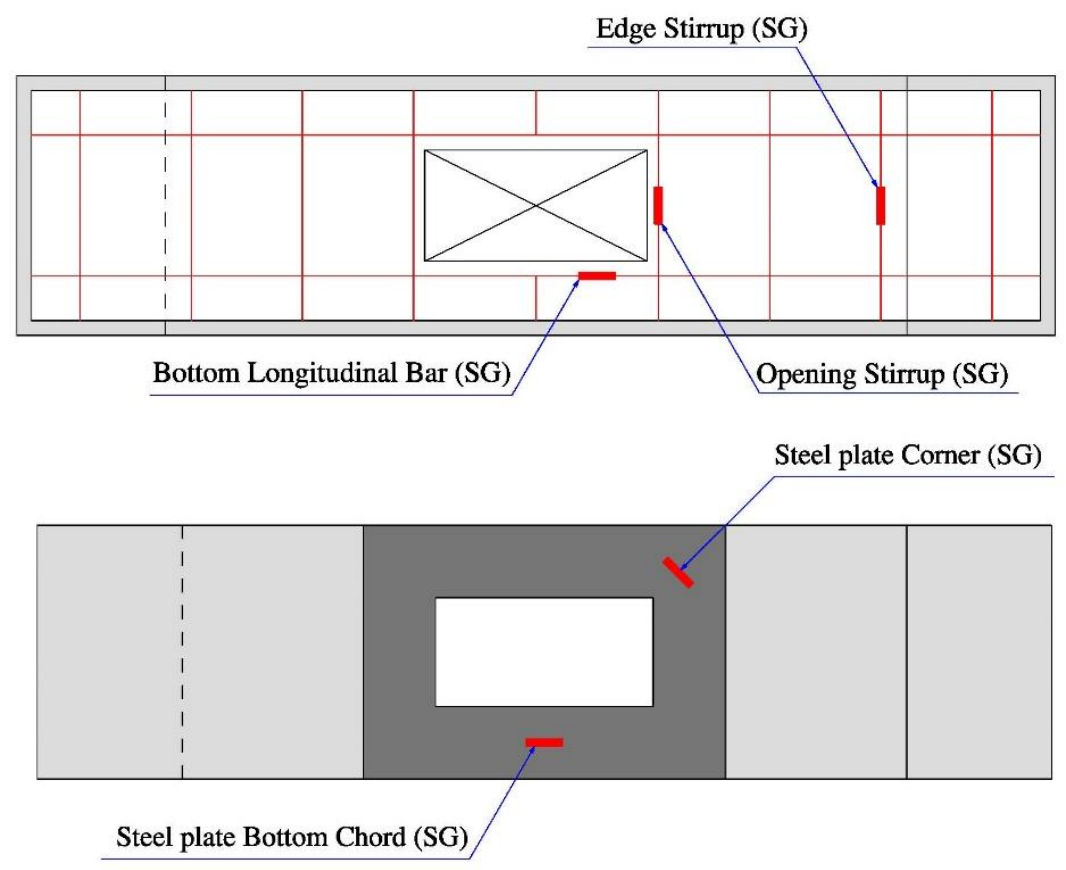

Figure 6 Schematic view for locations of strain gauges

\section{RESULTS AND DISCUSSION}

Table 3 shows the results of all tested beams and compared with the unrepaired reference specimens in each group. For group A, the cracking torque was $9.13 \mathrm{kN}$.m for the solid beam C-0, while it was $4.06 \mathrm{kN} . \mathrm{m}$ for beam C-300 with opening $300 \times 150 \mathrm{~mm}$. On the other hand, the cracking torques of the repaired beams R-300-3, and R-300-3-S are $3.65 \mathrm{kN} . \mathrm{m}$ and 4.26 $\mathrm{kN} . \mathrm{m}$, respectively. It has to be noted that in this group the full steel plate configuration had the highest ultimate torque of $13.19 \mathrm{kN}$.m followed by the steel strips configuration with an ultimate torque of $10.56 \mathrm{kN}$.m.

In group B, the cracking torque was $9.13 \mathrm{kN} . \mathrm{m}, 4.06 \mathrm{kN} . \mathrm{m}$, and $3.04 \mathrm{kN} . \mathrm{m}$ for beams C-0, C-300, and C-500, respectively. Such moment was $3.65 \mathrm{kN} . \mathrm{m}$, and $2.03 \mathrm{kN} . \mathrm{m}$ for the repaired beams R-300-3, and R-500-3, respectively. The results show that keeping the opening height constant and increasing the opening width from $300 \mathrm{~mm}$ to $500 \mathrm{~mm}$, leads to decrease in the ultimate torque from $13.19 \mathrm{kN} . \mathrm{m}$, to $12.18 \mathrm{kN}$.m, for beams R-300-3 and R-500-3, respectively. The ultimate torque for beams C-300 and C-500 with openings and without steel plates was 
$9.54 \mathrm{kN} . \mathrm{m}$ and $5.68 \mathrm{kN} . \mathrm{m}$, respectively. These results show the significant effect of steel plates in substituting the reduction in cross section of the beam due to the presence of the opening.

In group C, the cracking torque was $9.13 \mathrm{kN} . \mathrm{m}$, and $4.06 \mathrm{kN} . \mathrm{m}$ for beams C-0, and C-300, respectively, and $3.65 \mathrm{kN} . \mathrm{m}$, and $4.67 \mathrm{kN} . \mathrm{m}$ for beams R-300-3, and R-300-6, respectively. The increase in the steel plate thickness from $3 \mathrm{~mm}$ to $6 \mathrm{~mm}$ leads to increase in the ultimate torque by only $11 \%$.

Table 3 Results of all tested beams

\begin{tabular}{|l|l|l|l|l|l|}
\hline \multicolumn{1}{|c|}{ Beam } & $\begin{array}{c}\mathbf{T}_{\text {cr }} \\
(\mathbf{k N . m})\end{array}$ & $\begin{array}{c}\mathbf{T}_{\text {ult }} \\
(\mathbf{k N . m})\end{array}$ & $\begin{array}{c}\boldsymbol{\theta}_{\text {ult }} \\
(\mathbf{r a d} / \mathbf{m})\end{array}$ & $\begin{array}{c}\text { Increased } \\
\text { Capacity } \%\end{array}$ & \multicolumn{1}{c|}{ Mode of Failure } \\
\hline C-0 & 9.13 & 10.15 & 0.011 & - & Sudden torsional shear failure \\
\hline C-300 & 4.06 & 9.54 & 0.018 & - & $\begin{array}{l}\text { Crushing of concrete and cover } \\
\text { separation }\end{array}$ \\
\hline C-500 & 3.04 & 5.68 & 0.032 & -- & $\begin{array}{l}\text { Crushing of concrete and cover } \\
\text { separation }\end{array}$ \\
\hline R-300-3 & 3.65 & 13.19 & 0.021 & $38 \%$ & $\begin{array}{l}\text { Crushing of concrete and cover } \\
\text { separation beside the opening }\end{array}$ \\
\hline R-300-3-S & 4.26 & 10.56 & 0.059 & $11 \%$ & $\begin{array}{l}\text { Debonding of steel plates and concrete } \\
\text { cover separation }\end{array}$ \\
\hline R-300-6 & 4.67 & 14.62 & 0.037 & $53 \%$ & $\begin{array}{l}\text { Crushing of concrete and cover } \\
\text { separation beside the opening }\end{array}$ \\
\hline R-500-3 & 2.03 & 12.18 & 0.032 & $114 \%$ & $\begin{array}{l}\text { Sudden torsional shear failure through } \\
\text { the opening }\end{array}$ \\
\hline
\end{tabular}

\subsection{Mode of failure}

The reference unrepaired specimen $\mathrm{C}-0$ experienced a sudden torsional shear failure close to the supports which occurred suddenly at an ultimate torque of $10.15 \mathrm{kN} . \mathrm{m}$ as shown in Fig. 7(a). Control beams C-300, and C-500 failed at an ultimate torques of 9.54, and $5.68 \mathrm{kN} . \mathrm{m}$, respectively. These two beams failed due to separation of the concrete cover and crushing of concrete at the top and bottom chords of the opening as shown in Fig. 7(b) and Fig. 7(c).

The failure of the repaired beam R-300-3 occurred due to separation of the concrete cover near the supports and beside the steel plate at an ultimate torque of $13.19 \mathrm{kN}$.m with $38 \%$ increase in capacity compared to the control beam C-300 as shown in Fig. 7(d). While beam R300-3-S which was repaired with steel plate strips with thickness of $3 \mathrm{~mm}$ around the opening on the two sides of the beam, failed due to a sudden debonding of steel plates subsequent to the splitting of concrete cover at an ultimate torque of $10.56 \mathrm{kN}$.m with $11 \%$ increase in capacity compared to the control beam C-300 as shown in Fig. 7(e).

The repaired beam R-500-3 experienced a sudden torsional shear failure through the opening at an ultimate torque of $12.18 \mathrm{kN}$.m with $114 \%$ increase in capacity compared to the control beam C-500 as shown in Fig. 7(f). The failure of the repaired beam R-300-6 was due to crushing of concrete and cover separation beside the opening at an ultimate torque of 14.62 kN.m with $53 \%$ increase in capacity compared to the control beam C-300 as shown in Fig. $7(\mathrm{~g})$. 
Repair of Rc Beams with Openings Subjected to Torsion Using Steel Plates

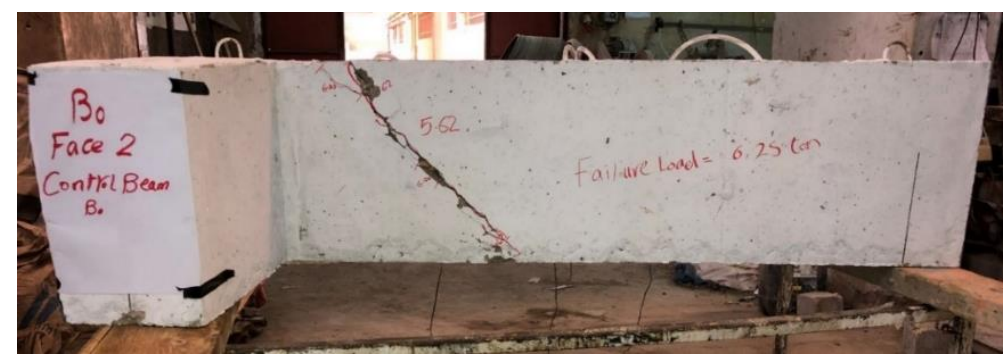

(a) Crack propagation and mode of failure for the control beam (C-0)

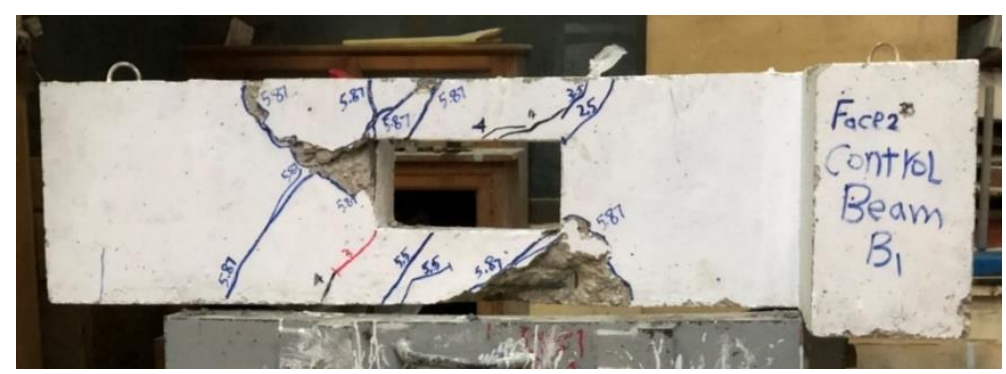

(b) Crack propagation and mode of failure for the control beam (C-300)

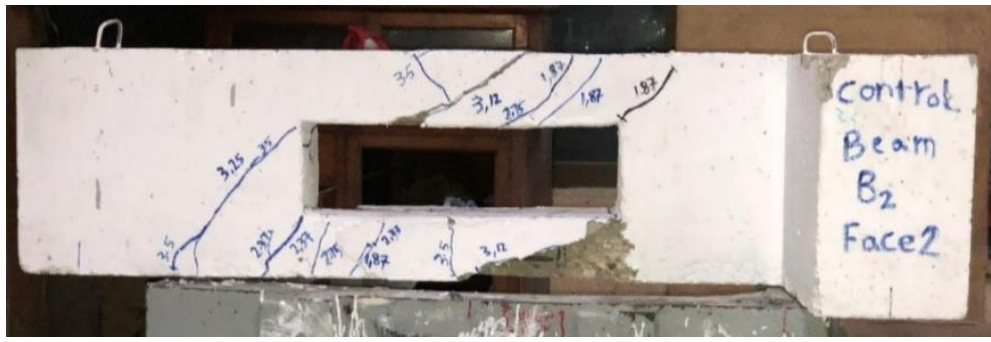

(c) Crack propagation and mode of failure for the control beam (C-500)

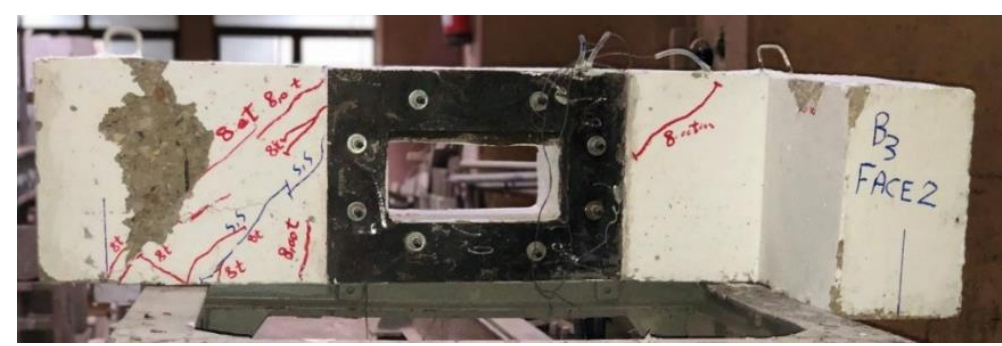

(d) Crack propagation and mode of failure for beam (R-300-3) after repairing

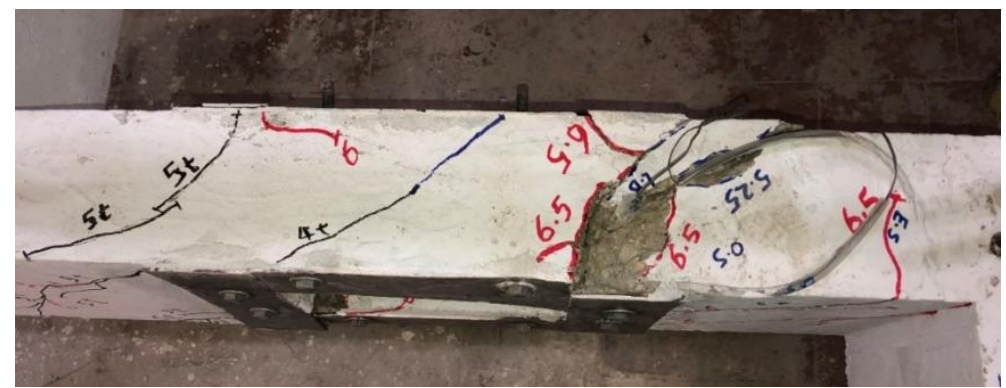

(e) Crack propagation and mode of failure for beam (R-300-3-S) after repairing 


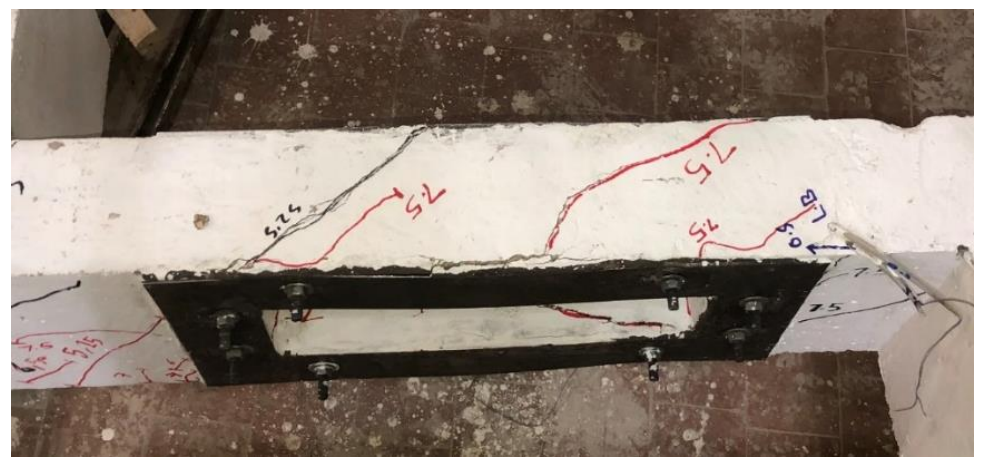

(f) Crack propagation and failure mode for beam (R-500-3) after repairing

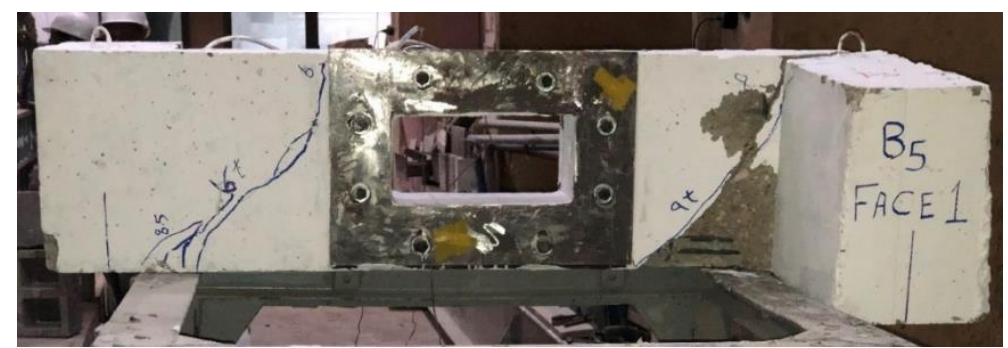

(g) Crack propagation and mode of failure for beam (R-300-6) after repairing

Figure 7 Mode of failure of all tested specimens

\subsection{Angle of Rotation}

The torque - rotation angle relation for the specimens of group A is shown in Fig. 8. The rotation angles were recorded at ultimate torque as $0.011,0.018,0.021$, and $0.059 \mathrm{rad} / \mathrm{m}$ for specimens C-0, C-300, R-300-3, and R-300-3-S, respectively. It was observed that the rotation angle increased by $16 \%$, and $224 \%$ for the repaired beams R-300-3, and R-300-3-S compared to the control beam C-0.

Fig. 9 shows the torque - rotation angle relation for the specimens of group B. The results indicate that repairing of specimen with full steel plates with thickness of $3 \mathrm{~mm}$ as in specimen R-500-3 did not have a significant effect on the angle of rotation in comparison with the control specimen C-500. The angle of rotation increased by $16 \%$ for specimen R-300-3 which repaired with the same $3 \mathrm{~mm}$ steel plates configuration. The corresponding angles at the ultimate torque were $0.011,0.018,0.032,0.021$, and $0.032 \mathrm{rad} / \mathrm{m}$ for specimens C-0, C-300, C-500, R-300-3, and R-500-3, respectively.

From Fig. 10, the angles of rotation for the specimens of group $\mathrm{C}$ at the ultimate torque were $0.011,0.018,0.021$, and $0.037 \mathrm{rad} / \mathrm{m}$, for specimens C-0, C-300, R-300-3, and R-300-6, respectively. It is noted that repairing of specimen R-300-6 with full steel plates of $6 \mathrm{~mm}$ thickness increased the angle by $102 \%$. The increase in angle of rotation was $16 \%$ for specimen R-300-3 which repaired with full steel plates of $3 \mathrm{~mm}$ thickness. 
Repair of Rc Beams with Openings Subjected to Torsion Using Steel Plates

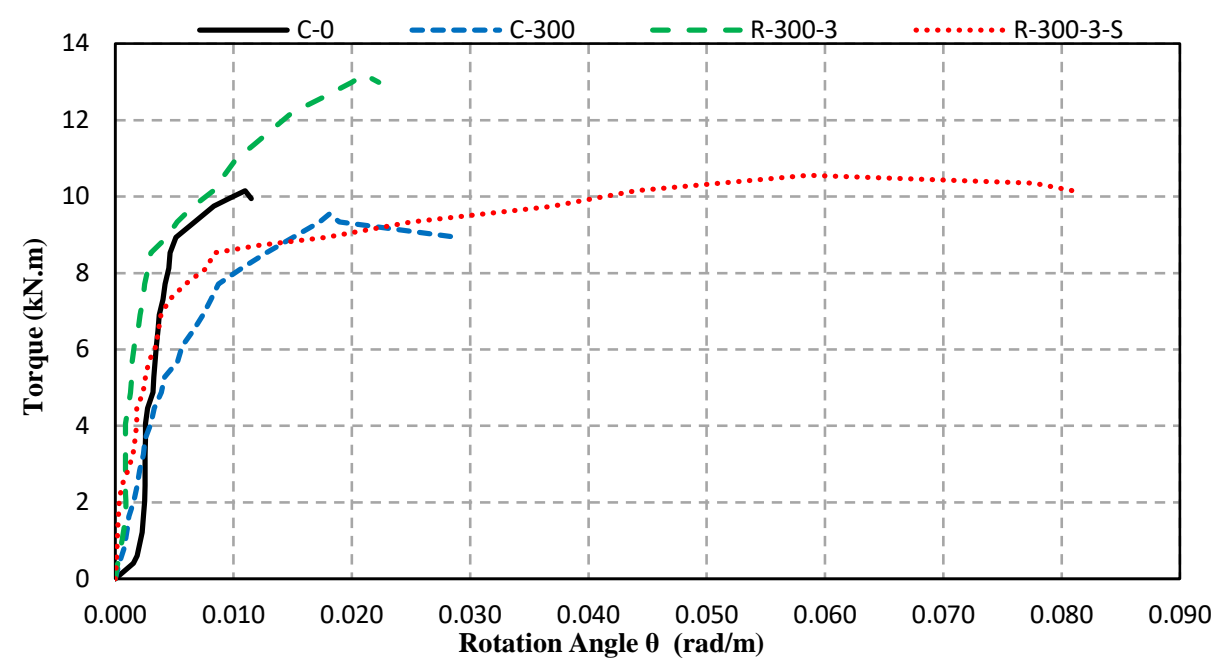

Figure 8 The torque - rotation angle relation for group A specimens

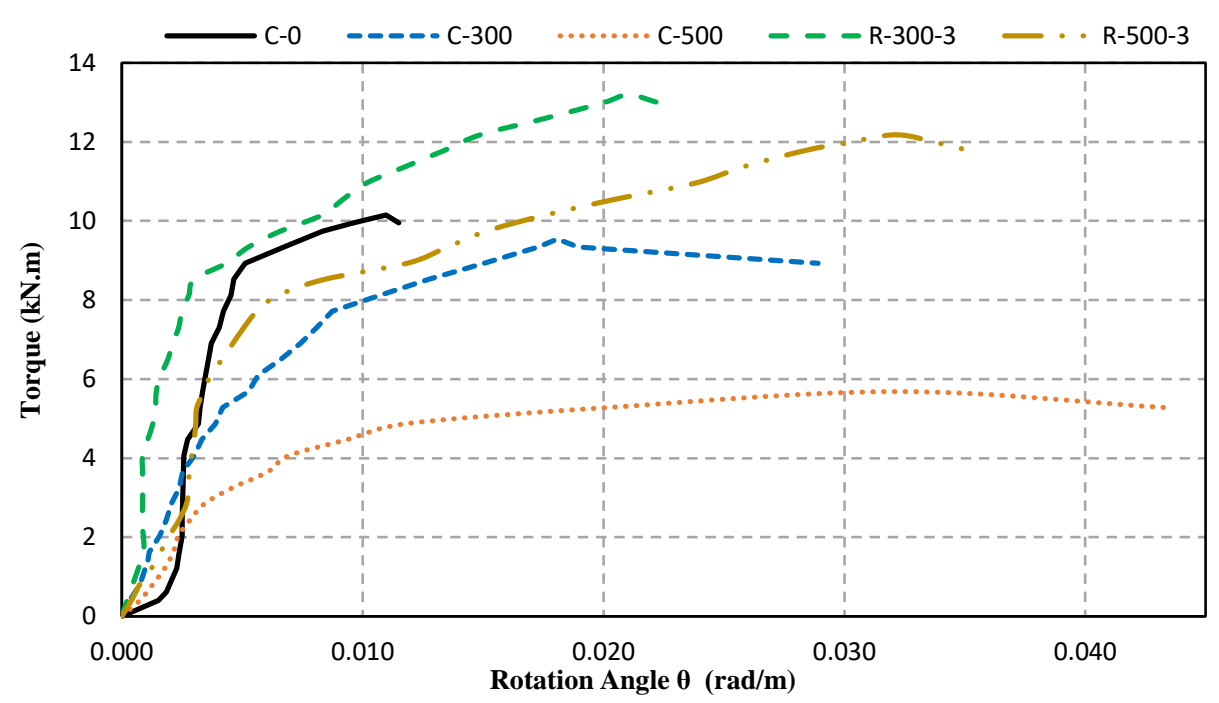

Figure 9 The torque - rotation angle relation for group B specimens

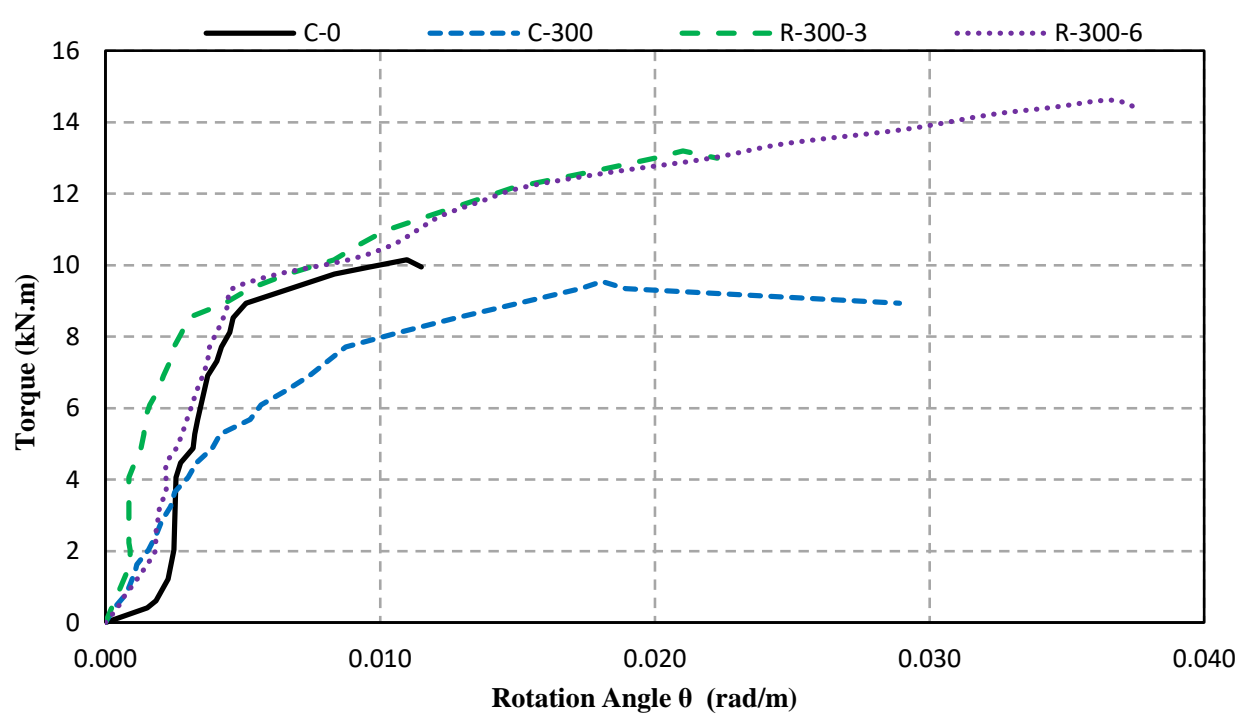

Figure 10 The torque - rotation angle relation for group $\mathrm{C}$ specimens 


\subsection{Comparison between the repaired beams}

Fig. 11 shows the results of the repaired specimens of group A as compared to the reference beam C-300. The torsional toughness is defined as the area under the torque - rotation angle curve which refers to the absorbed energy capacity from the beginning of loading till the failure of the specimen. It was observed that specimen R-300-3-S repaired by steel strips had the highest increase in torsional toughness by $248 \%$ followed by specimen R-300-3 repaired with full steel plates by $5 \%$.

From Fig. 12, the results of the specimens of group B are compared with control specimen C-300 and C-500. Specimen R-500-3 which repaired with full steel plates with thickness of 3 $\mathrm{mm}$ had the highest increase in torsional toughness by $59 \%$ followed by specimen R-300-3 repaired by $3 \mathrm{~mm}$ steel plates with $5 \%$ increase.

Fig. 13 illustrates the summary of results of the specimens of group $\mathrm{C}$ compared with control specimen C-300. The results show that specimen R-300-6 which repaired with full steel plates with thickness of $6 \mathrm{~mm}$ had the highest increase in torsional toughness by $96 \%$ followed by specimen R-300-3 repaired by $3 \mathrm{~mm}$ steel plates with $5 \%$ increase.

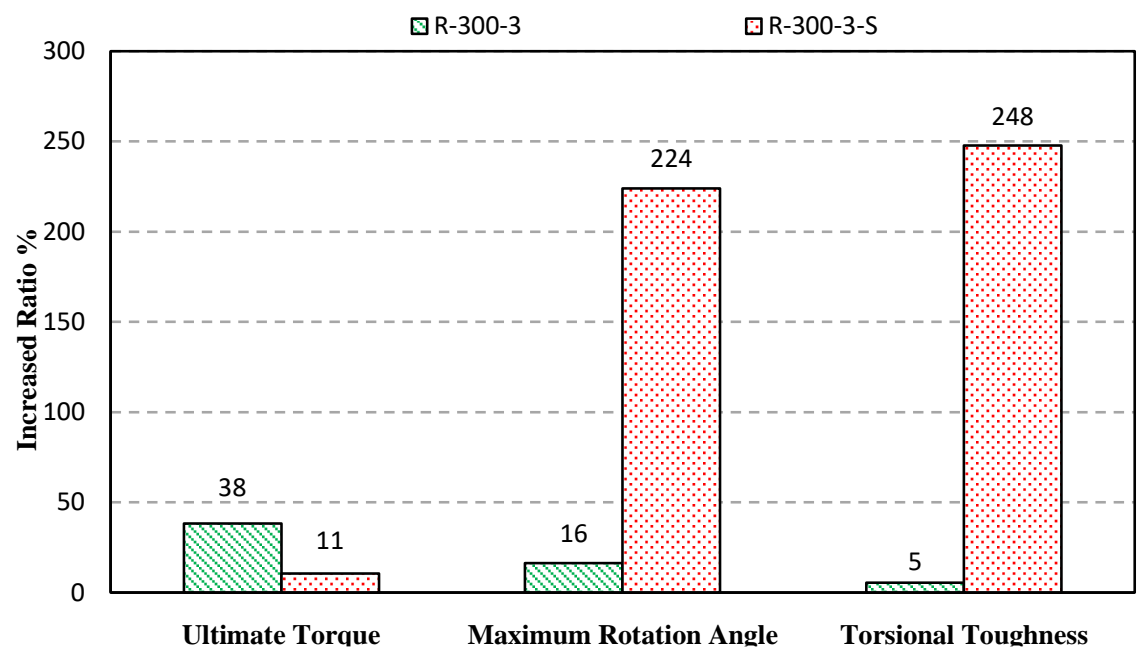

Figure 11 Results of the repaired specimens of group A compared to the control beam C-300

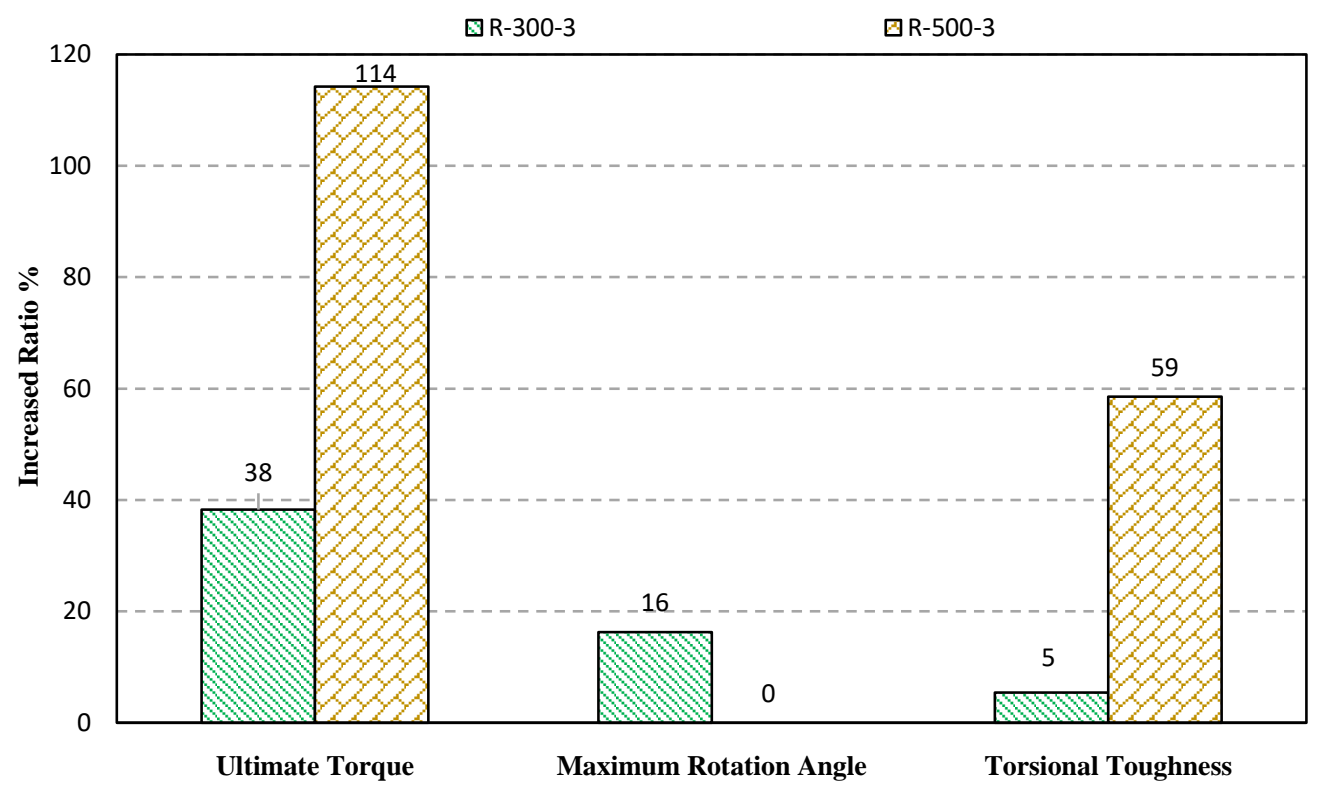

Figure 12 Results of the repaired specimens of group B compared to the control beams C-300, C-500 
Repair of Rc Beams with Openings Subjected to Torsion Using Steel Plates

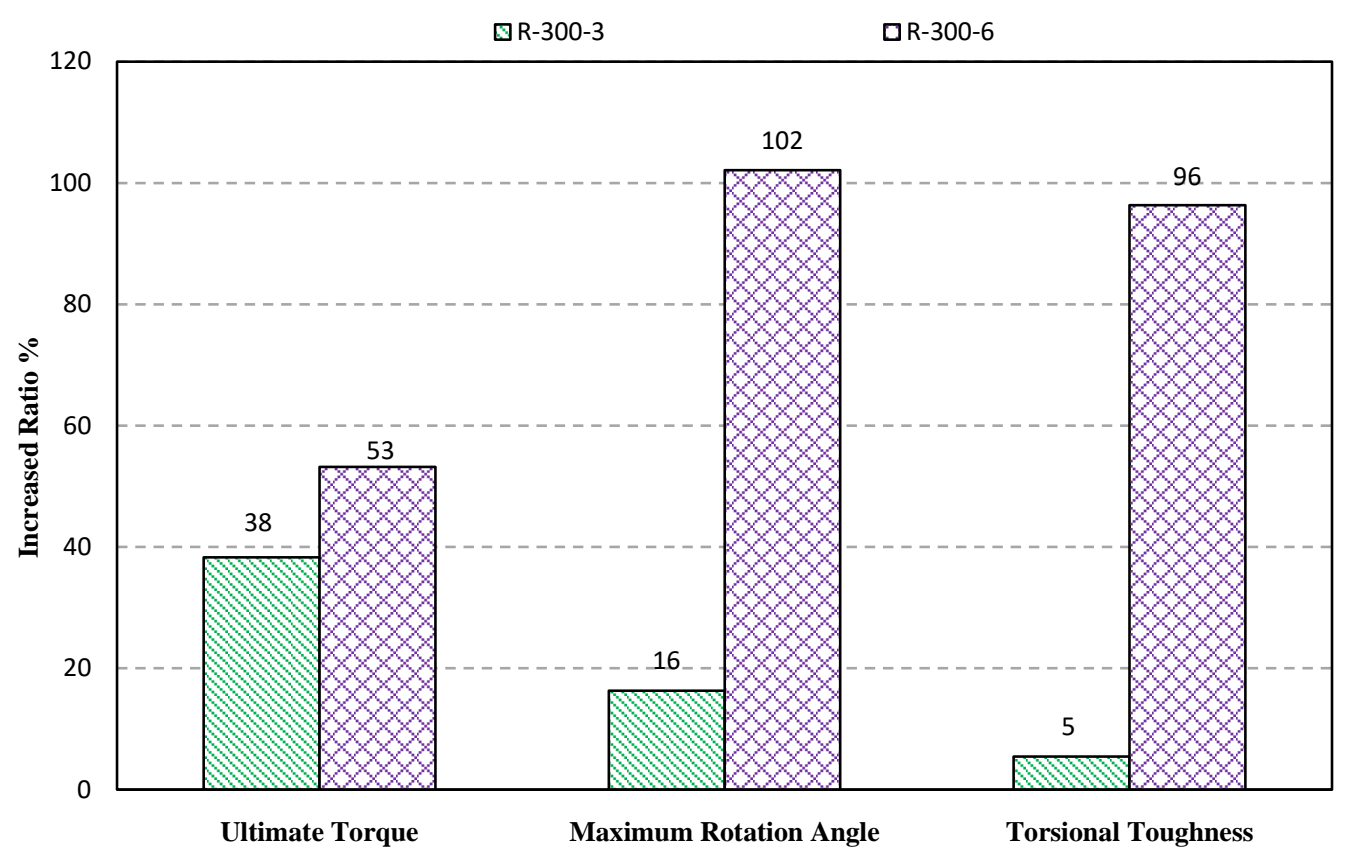

Figure 13 Results of the repaired specimens of group C compared to the control beam C-300

\subsection{Cost Analysis Study}

A cost analysis study was performed to compare between the different repair configurations used in this research. The results may help structural engineers to decide the most effective repair method and configuration in beams with openings under torsional loading. The results show that the repair using steel strips instead of full plate gives the lowest capacity gain per unit price as shown in Fig. 14. Also, using of steel plates for repair against torsion is greatly effective specially for wide openings. The steel plates provided at the beam sides proved to be an accepted substitute for the concrete taken out by the opening.

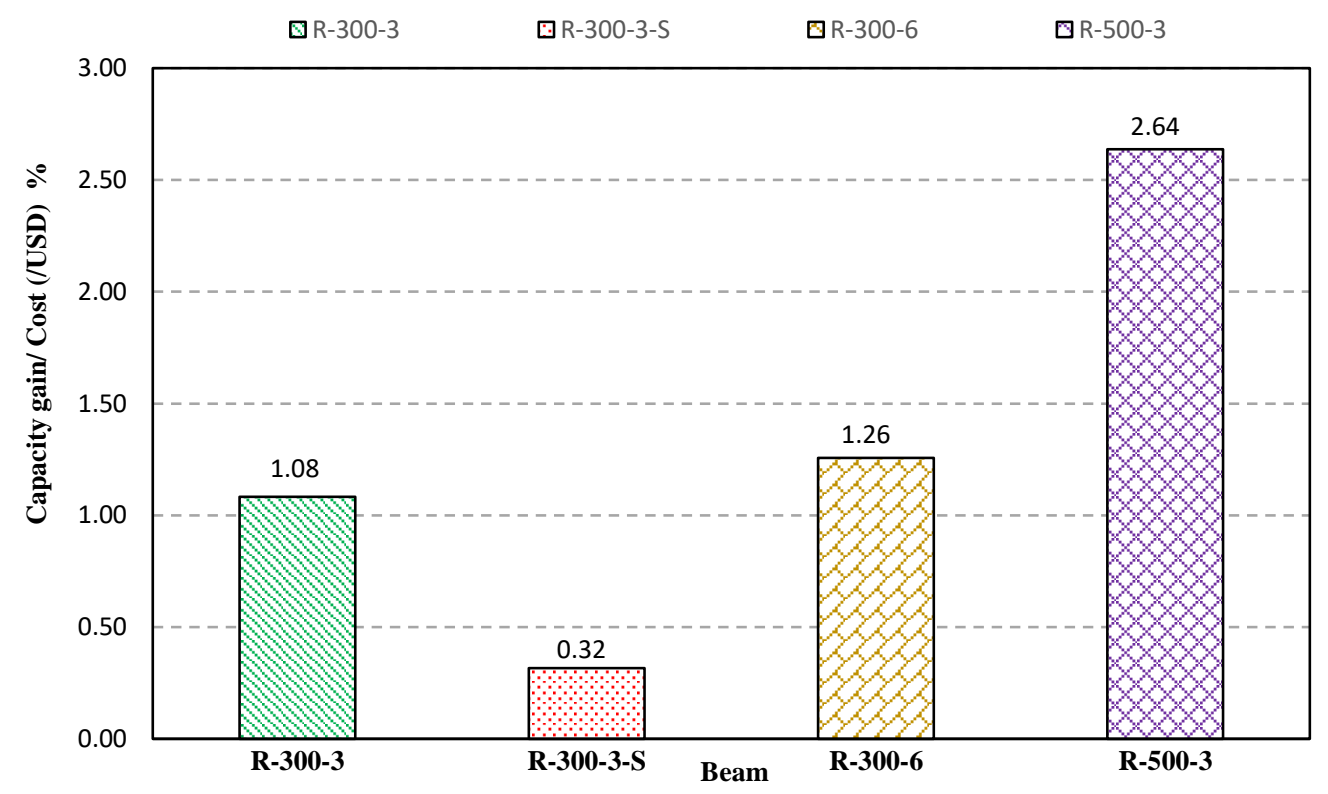

Figure 14 Percentage of capacity gain per unit cost (USD) for repaired specimens 


\section{CONCLUSIONS}

Based on the experimental results of this research and within the investigated parameters, the following conclusions can be made:

1. Keeping the opening height constant, the opening width of $30 \%$ of the tested span decreased the ultimate torque by $6 \%$ only. The ultimate torque decreased by $44 \%$, when the openings width reached $50 \%$ of the tested length. This shows that opening width is very critical in beams subjected to torsion.

2. Using full steel plates configuration is more effective than using steel strips in repairing beams with openings subjected to torsion. The ultimate torque increased by $38 \%$, and $11 \%$ in case of using full steel plates and steel strips respectively. The angle of rotation increased by $16 \%$, and $224 \%$ in case of repairing with full steel plates and steel strips respectively.

3. Repairing of beams with openings of $300 \mathrm{~mm}$ and $500 \mathrm{~mm}$ width using full steel plate of $3 \mathrm{~mm}$ increased the ultimate torque by $38 \%$ and $114 \%$, respectively.

4. The ultimate torque increased by $38 \%$ and $53 \%$, using steel plates with thickness of 3 $\mathrm{mm}$ and $6 \mathrm{~mm}$, respectively. The torsional toughness increased by $5 \%$ and $96 \%$ in case of repairing with steel plates with thickness of $3 \mathrm{~mm}$ and $6 \mathrm{~mm}$, respectively.

5. The angle of rotation for the repaired specimens increased by $16 \%$ and $102 \%$ in case of repairing with steel plates with thickness of $3 \mathrm{~mm}$ and $6 \mathrm{~mm}$, respectively.

6. The results show that the repair using full plates instead of steel strips gives more effective capacity gain per unit price.

7. The steel plates provided at the beam sides proved to be an accepted substitute for the concrete taken out by the opening.

\section{CONFLICTS OF INTEREST}

The authors declare no conflict of interest.

\section{REFERENCES}

[1] T. Abdo and R. Mabrouk, "Effect of web openings on the structural behavior of RC beams subjected to pure torsion," in MATEC Web of Conferences, Aug. 2017, vol. 120, doi: 10.1051/matecconf/201712001007.

[2] M. A. Mansur, S. K. Ting, and S. Lee, “Torsion Tests of R/C Beams With Large Openings," J. Struct. Eng., vol. 109, no. 8, pp. 1780-1791, Aug. 1983, doi: 10.1061/(asce)07339445(1983)109:8(1780).

[3] A. E. Salama, M. E. Kassem, and A. A. Mahmoud, "Torsional behavior of T- shaped reinforced concrete beams with large web openings," J. Build. Eng., vol. 18, pp. 84-94, 2018, doi: 10.1016/j.jobe.2018.02.004.

[4] M. Makhlouf, "Torsional Behavior of RC Beams with Opening Using (CFRP - GFRP - Steel) Stirrups," Adv. Res., vol. 8, no. 3, pp. 1-10, Jan. 2016, doi: 10.9734/air/2016/30247.

[5] J. W. Holman and J. P. Cook, "Steel Plates for Torsion Repair of Concrete Beams," J. Struct. Eng., vol. 110, no. 1, pp. 10-18, Jan. 1984, doi: 10.1061/(ASCE)0733-9445(1984)110:1(10).

[6] E. E. Etman and M. H. Marzouk, "REPAIR OF REINFORCED CONCRETE BEAMS PRECRACKED IN TORSION," in IC-SGECT '04 International Conference on Structural \& Geotechnical Engineering and Construction Technology International Conference on Structural \& Geotechnical Engineering and Construction Technology, 2004, pp. 841-850.

[7] K. Fawzy, "Relative Study of Nonlinear Analysis for Torsional Strengthened RC Beams with Web Opening using CFRP and Steel Plates," IOSR J. Mech. Civ. Eng. e-ISSN, vol. 15, no. 1, pp. 65-78, 2018, doi: 10.9790/1684-1501026578. 
[8] K. Fawzy, M. M. Hashem, and A. M. Elnady, "Performance of RC Beams with web Opening Subjected to Pure Torsion Strengthened with CFRP," Int. J. Eng. Innov. Technol., vol. 4, no. 1, pp. 197-204, 2014.

[9] W. B. Domat, "Repair of R.C. Beams Subjected to Torsion Using CFRP Sheets," Faculty of Engineering, Cairo University, 2018.

[10] R. S. Atea, "Torsional Behavior of Reinforced Concrete T-Beams Strengthened with CFRP Strips," Case Stud. Constr. Mater., vol. 7, pp. 110-117, Dec. 2017, doi: 10.1016/j.cscm.2017.03.002.

[11] G. Hekal, B. Ramadan, and N. Meleka, "Behavior of RC Beams with Large Openings Subjected to Pure Torsion and Retrofitted by Steel or CFRP Plates," ERJ. Eng. Res. J., vol. 43, no. 2, pp. 127-138, Apr. 2020, doi: 10.21608/erjm.2020.83910.

[12] N. Habeeb Askandar and A. Darweesh Mahmood, "Torsional Strengthening of RC Beams with Near-Surface Mounted Steel Bars," Adv. Mater. Sci. Eng., vol. 2020, pp. 1-11, 2020, doi: $10.1155 / 2020 / 1492980$.

[13] S. B. Kandekar and R. S. Talikoti, "Torsional behaviour of reinforced concrete beam wrapped with aramid fiber," J. King Saud Univ. - Eng. Sci., vol. 31, no. 4, pp. 340-344, Oct. 2019, doi: 10.1016/j.jksues.2018.02.001.

[14] M. Y. Alabdulhady, L. H. Sneed, and C. Carloni, "Torsional behavior of RC beams strengthened with PBO-FRCM composite - An experimental study," Eng. Struct., vol. 136, pp. 393-405, 2017, doi: 10.1016/j.engstruct.2017.01.044.

[15] "Addicrete BVF," Chemicals for Modern Building International. https://www.cmbegypt.com/cmb/en/pdf/4-admixtures/addicrete BVF.pdf.

[16] "Kemapoxy 165," Chemicals for Modern Building International. http://cmbegypt.com/cmb/en/wpcontent/pdf/Chemical_construction/06_construction_repair_strengthening/5.kemapoxy 165/kemapoxy 165.pdf. 